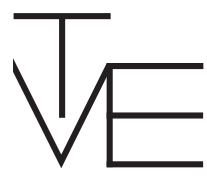

\title{
Marketing communication towards cruise ship passengers: the implications of market segmentation
}

\author{
Gunnar Óskarsson and Irena Georgsdóttir ${ }^{1}$
}

\begin{abstract}
Tourism in Iceland has been growing incredibly fast during the past years; for example, the cruise industry has grown at a rapid rate, as Iceland continues to gain popularity as a cruise destination. Although a certain amount of research has been conducted in this sphere, it does not cover all of the important issues, including a better insight into clustering of cruise ship passengers, who differ from other tourists in a number of ways, and marketing communication towards them regarding product and services offered at the point of destination. The main objective of this research is to examine factors that have an impact on potential segmentation of cruise ship passengers coming to Iceland and learn about marketing communication practices used by local companies offering them products and services. Qualitative research was used as an approach and personal interviews chosen as a means of collecting information. Interviews were taken with 10 people from different companies who interact with cruise passengers on a regular basis at their workplace. The main findings reveal that participants note the strongest difference between cruise passengers of different nationalities, passengers coming on different ships (size and type), and passengers arriving at different times of the year. Concerning marketing communication towards cruise passengers,
\end{abstract}

1 Gunnar Óskarsson has a Ph.D. in business administration from the University of Iceland and is an assistant professor in the Faculty of business administration at the University of Iceland, with main emphasis on the management of innovation and international business. E-mail: gunnaros@hi.is. Irena Georgsdóttir has an M.Sc. in marketing and international business from the University of Iceland. 
the results indicate that it is almost exclusively carried out through the Internet; a reliable website, search engine optimization and word-of-mouth. This research provides a contribution by deepening understanding of approaches that may be effective in market segmentation in this particular section of the tourism industry and identifying effective ways to reach potential customers. This research thus provides a significant addition to marketing knowledge for an increasingly important sector of the tourist industry.

JEL classification: M31

Keywords: Market segmentation; cruise ships; tourism; market communication.

\section{Introduction}

Tourism in Iceland has been growing rapidly during the past years with the number of incoming tourists increasing almost four-fold from 2000-2015 (Icelandic Tourist Board, 2016; Óladóttir, 2015a). Cruise industry growth rate has been even higher, as Iceland continues to gain popularity as a cruise destination. Thus, the number of cruise passengers visiting Iceland increased from 27,000 in 2000 to 104,800 in 2014 (Óladóttir, 2015b). It is important to keep in mind, however, that while the number of foreign visitors arriving in Iceland has been growing every year, expenditure per visitor has remained constant for over a decade (Boston Consulting Group, 2013). Therefore, the primary focus of tourism development should be on quality over quantity. This applies particularly to the cruise industry because cruise passengers stay for the shortest period of time onshore, and spend less per head than other tourists (Huijbens \& Gunnarsson, 2014; Larsen, Wolff, Marnburg, \& Øgaard, 2013). Furthermore, as cruise ship passengers arrive in groups, sometimes quite large, and are not a homogenous group, it is not advisable to offer them all the same product or service. Furthermore, service providers at the destination only have limited access to the passengers before they arrive. This leads to the following research questions:

1. Which factors have an impact on potential segmentation of cruise ship passengers?

2. In what ways is information on Icelandic tourist products and services communicated towards cruise ship passengers?

The next section of the article provides an introduction to cruise tourism, including a summary of the situation and developments in Iceland. The paper then moves on to a review of the literature on market segmentation, both in 
general and specifically regarding cruise ship passengers, concluding with a brief insight into marketing approach and communication. Furthermore, a short discussion on target marketing is included, as this contributes to an understanding of the value of market segmentation. The review highlights the importance of segmenting cruise passengers and the most effective means of market communication towards them. Finally, a description of the methodology applied in the research is presented; the last part consisting of discussions, conclusions and limitations.

\subsection{Introduction to cruise tourism}

Cruise tourism is generally defined as time spent on a waterborne vessel for leisure purposes (Nilsson, 2007, citing Cartwright, 1999; Sillignakis, 2007). The cruise industry is a relatively young and, undeniably, a strongly growing segment of tourism (Weeden, Lester, \& Thyne, 2011). Along with its rapid expansion, the cruise industry is undergoing constant transformation. In the beginning, cruising was an exclusive luxury for the rich, famous and mostly elderly members of society. With time, however, interest has been growing among wider circles of the population and so has competition (Weeden et al., 2011). Together, these trends have resulted in the introduction of more diversified products serving various customer categories, including younger people, families and multi-generation groups (Gulliksen, 2008). The average age of a cruise passenger dropped from 65 in the 1970s down to 46 in 2008; prices have become more affordable as well (Elliot \& Choi, 2011). Cruise lines pay close attention to their customers' vacation desires and develop new itineraries and destinations, as well as innovative ship designs, constantly introducing new services, facilities and entertainment. They also provide a wide choice of cruises varying from a few days to a few weeks in duration; the average was 7.2 days in 2013 (FCCA, 2013). Another relevant change is that a cruise trip is no longer considered a once in a lifetime experience, as $85 \%$ of cruise passengers have cruised before (Elliot \& Choi, 2011).

North American passengers still constitute the largest cruise market segment, although markets in Europe, Asia and the rest of the world are showing strong growth tendencies (CLIA, 2015). Table 1 represents how cruise passengers are divided between source markets. 
Table 1: Cruise Passengers by source market 2014

\begin{tabular}{lrlr}
\hline $\begin{array}{l}\text { Source markets } \\
\text { World }\end{array}$ & $\begin{array}{r}\text { Passengers } \\
\text { (millions) }\end{array}$ & $\begin{array}{l}\text { Source markets } \\
\text { Europe }\end{array}$ & $\begin{array}{r}\text { Passengers } \\
\text { (millions) }\end{array}$ \\
\hline North America & 12.16 & Germany & 1.77 \\
Europe & 6.39 & UK/Ireland & 1.64 \\
Asia/Pacific & 2.40 & Italy & 0.84 \\
Rest of the World & 1.09 & France & 0.59 \\
& & Spain & 0.45 \\
& & Europe, other & 1.10 \\
\hline Total & 22.04 & Total & 6.39 \\
\hline
\end{tabular}

Source: CLIA, 2015

The cruise industry has undergone strong consolidation, as more than $76 \%$ of market share in 2015 belonged to the three largest companies, as seen in Table 2. All of them retain their strong positions from the 1970s (Klein, 2003).

Table 2: Market share of cruise companies

\begin{tabular}{lr}
\hline Cruise company & Market Share \\
\hline Carnival Corporation & $42.2 \%$ \\
Royal Caribbean Cruises & $22.1 \%$ \\
Norwegian Cruise Line & $12.4 \%$ \\
All others & $23.3 \%$ \\
\hline
\end{tabular}

Source: The Statistics Portal (2016)

\subsection{New trends}

Ever-changing customer tastes and preferences apply to cruising as much as any other industry, calling for the emergence of new trends and tendencies. At least three distinct recent trends can be identified for the cruise industry.

The first concerns the size of cruise ships. Since the very dawn of leisure cruising the majority of cruise lines were in a "race" for the largest ship. Innovative technologies and huge resources were dedicated to creating more spacious vessels, constantly increasing the number of amenities and entertainment facilities, thus turning ships into "floating hotels". Nevertheless, recently this concept seems to have become less popular, as cruise passengers are looking for more sense of privacy and new, different experiences and entertainments (Harpaz, 2014). It is possible that this shift in priorities has to some extent stimulated the considerable increase in demand for river cruises as well (Cruise Critic, 2014).

The second trend touches upon ships' qualities and facilities. Two evaluation criteria for cruise ships and lines have gained considerable importance 
- the quality and originality of dining options and availability of technical equipment. The former has become a famous self-sufficient entertainment and the latter is a strong factor of convenience (Harpaz, 2014). As, for example, the Internet becomes accessible to people nearly everywhere, surely cruise ships should be no exception (Sloan, 2014).

The third trend is mostly due to external influence. The highly competitive environment in the light of galloping globalization causes companies from various spheres to take on more social responsibility and become notably environmentally aware and health conscious. The cruise lines follow this pattern: they are constantly working on technologies of waste filtering and minimizing the volume of refuse. They also enlarge non-smoking areas on board, although this is primarily for reasons of comfort, as cigarette fumes might disturb non-smoking passengers (Cruise Critic, 2014).

\subsection{Icelandic perspective}

The cruise industry in Iceland is growing at a high rate; between the years 2000 to 2014 alone, the number of passengers in the port of Reykjavík grew by close to fourfold - from 27,000 to 104,800 - which constitutes an average growth of approximately $12 \%$ per annum (Óladóttir, 2015a). The most visited ports of call are listed in table 3.

Table 3: Most visited ports in Iceland 2014

\begin{tabular}{lr}
\hline Port & Number of passengers \\
\hline Reykjavik & 104,800 \\
Akureyri & 72,700 \\
Ísafjörður & 40,300 \\
Vestmannaeyjar and Seyðisfjörður & 14,900 \\
\hline
\end{tabular}

Source: Icelandic Tourist Board (2015)

It is interesting to note the nationality of cruise passengers compared to tourists in general arriving to Iceland. The high share of cruise passengers from Germany compared to tourists in general is noteworthy, indicating an opportunity for Icelandic companies serving cruise passengers. Apart from that, there are no large distinctions; tourists from the United States and the United Kingdom are a considerable proportion of tourists arriving in Iceland, regardless of whether they arrive on cruise ships or by other means.

An important question is how to maintain the strong standing of Icelandic tourism for the benefit of local populations whilst protecting resources. After the bank crisis and collapse of the Icelandic krona, it became less expensive to visit Iceland, which, amongst other things, contributed to its heightened popularity as a travel destination. Accordingly, the number of tourists visiting 
the country grew from 562,800 in 2009 to 1,074,000 in 2014 (Óladóttir, 2015a). But such a rapidly growing number of tourists also brings disadvantages (increased pollution and landscape deterioration, to mention but two obvious examples). The aim of the Travel Industry Association (SAF) and other stakeholders has thus veered towards quality over quantity. For example, in a report prepared by the Boston Consulting Group in 2013,

Table 4: Tourists arriving in Iceland 2016 by nationality

\begin{tabular}{lrr}
\hline Nationality & $\begin{array}{r}\text { Tourists in } \\
\text { General }\end{array}$ & $\begin{array}{r}\text { Cruise } \\
\text { passengers }\end{array}$ \\
\hline USA & $23.5 \%$ & $21.5 \%$ \\
UK & $17.9 \%$ & $20.2 \%$ \\
Germany & $7.5 \%$ & $30.9 \%$ \\
France & $4.8 \%$ & $2.3 \%$ \\
Canada & $4.7 \%$ & $3.3 \%$ \\
Other & $41.6 \%$ & $21.7 \%$ \\
\hline
\end{tabular}

commissioned by a consortium of private companies, four primary challenges facing tourism development in Iceland were emphasized (p.11):

$>$ Conserving natural attractions and preserving visitors' experience of them

$>$ Enabling higher visitor spending by delivering greater value to visitors

$>$ Reducing seasonality to mitigate pressure on capacity during peak summer months

$>$ Improving distribution of tourism to reduce pressure on the SouthWest and spread the benefits of tourism throughout the country

In order to achieve the results proposed by the researchers, a strategy was developed to target more attractive tourist segments, identified as Affluent Adventurers, Older Relaxers, Emerging Market Explorers, City Breakers and those travelling for business meetings and conferences (The Boston Consulting Group, 2013). Similar issues are raised in the report by Pannell Kerr Forster (PKF) commissioned by the public sector and published earlier in the same year. More emphasis is placed on supporting year-round tourist visits and moving towards sustainable tourism. The authors also stress the importance of carefully balancing the mix of tourists by combining volume with "high yield, low impact" tourists (PKF, 2013). 


\section{Literature review}

\subsection{Target marketing}

Markets are not homogeneous; on the contrary, they usually include customers who differ from each other in a number of aspects. Customers' motivations and constraints, beliefs and preferences, lifestyles and behaviour might vary greatly (Lilien \& Rangaswamy, 2004). Therefore the same basic needs or wants can best be satisfied by diversified products for different customers (Smith \& Cooper-Martin, 1997). It has been recognized for a long time that it is potentially valuable to customize products and services, as well as marketing activities towards different segments (Rossi, McCulloch, \& Allenby, 1996). The activity of aiming products and services towards a specific segment has been referred to as target marketing.

\subsubsection{Target Marketing in Tourism}

Target marketing is an essential part of the complex marketing activities in the tourism industry (Bhadauria \& Sanjoy Ghose, 2014; Bowen, 1998). There are numerous reasons for this. One of the most important is the fact that only a small, but growing, fraction of the world population can afford and chooses to conduct an international trip in any single year. Besides, this small percentage of the population is neither distributed evenly, nor randomly (European Travel Commission, 2007). The situation is most often the opposite: minorities within groups of the population account for the highest demand rates on tourism products and services. This phenomenon is sometimes called the Pareto principle (after the Italian social scientist who discovered it). Tourism propensity is a term commonly applied in the tourism industry to express the variation existing between segments or groups of people with regard to their likelihood to take an international trip. For example, North America and Western Europe have a higher tourism propensity than Africa and South America, which means that a larger percentage of the population of the former two continents travels abroad in any single year. Tourism propensity also varies between different segments within a region or a country. Thus people with higher incomes have a higher tourism propensity than those with lower earnings and people with longer paid vacations are more likely to travel abroad than those with shorter paid vacations (Seaton \& Bennett, 1996).

\subsection{Market segmentation}

The process of dividing actual and potential customers into smaller groups with distinct needs, characteristics, or behaviour has been referred to as market segmentation (Smith, 1993). It is important that the groups consist of customers whose valuations of a product or service differ only slightly within 
the segment but vary significantly among segments (Hoek et al., 1996). By dividing customers into groups, companies get an opportunity to study each of them better and scrutinize the segments they find the most suitable. This provides them with a possibility of a deeper understanding of customers' needs, wants and preferences and of developing offers accordingly (Dickson \& Ginter, 1987). There is, however, one difficult question every company must answer: how many segments should there be? Of course, every customer is unique, he/she is different from anyone else at least in one characteristic, and there is literature proposing the idea of ultimate segmentation, or "the segment of one" (Peppers \& Martha, 1994, 2001). It has, however, been argued, that such an approach might not be feasible, and it will in the future co-exist with traditional segmentation (Dibb, 2001).

One of the main goals companies try to achieve by segmenting markets is to identify differences in customers' responses to various marketing programmes (advertising, coupons, discounts, etc.). If customer segments do not exhibit different responses, this means they were identified incorrectly and thus will be of no use for marketing purposes. This can happen if the criteria used for the segmentation process have very little (or no) correlation with customers' responses to marketing programmes or customers' valuation of a product/service (Dillon et al., 1994). For example, age might or might not have such a correlation in different cases.

\subsubsection{Market segmentation in tourism}

Two main methods of segmentation are used in the tourism industry - a priori and post hoc (Dolnicar, 2002; Moscardo, Pearce, Morrison, Green, \& O'Leary, 2000). The a priori method studies travel behaviour (or what the tourists do), while the post hoc method is based on studying tourists as individuals (or who the tourists are). Moscardo et al., (2000) offered a model according to which two categories of segmentation variables pertain to each of the two methods. The categories and examples of variables are illustrated in table 5 .

Table 5: A priori and post hoc methods of segmentation

\begin{tabular}{lll} 
Methods & Categories & Variables \\
\hline A priori & Demographic & Gender, age, occupation, family size and stage, income \\
& Geographic & Residence location \\
\hline Post hoc & Psychological/lifestyle & $\begin{array}{l}\text { Beliefs, attitudes, values, personality features, benefits. } \\
\text { Behavioural }\end{array}$ \\
& $\begin{array}{l}\text { Types of trips taken, frequency of travelling, } \\
\text { information sources and distribution channels used. }\end{array}$ \\
\hline
\end{tabular}

Source: Moscardo et al. (2000) 
Dolnicar (2002) approaches the two methods from a slightly different angle. She uses the terms "commonsense" (for a priori) and "data-driven" (for post hoc) methods of segmentation. The difference between the two is based on whether the segmenting (grouping) criteria are determined in advance or not. In the commonsense method the variables deemed appropriate for the segmentation of a market are chosen (for example, age, occupation, origin, etc.) and set as a segmentation basis. The other variables on which data is available act as descriptors. In the data-driven method, it is, however, not known in advance how the segments will be formed, which variables will count as bases and which of them as descriptors; instead, they will be derived from the data. The first step is collecting data on several significant variables, usually by conducting a survey or obtaining data that has already been collected. Except for people's opinions and attitudes learned through surveys, the actual behavioural data can be used as well, such as visits to a website or click streams of online advertisements. The second step is data analysis, usually performed with the help of specialized software.

Both of the methods have their weak spots. Hoek et al. (1996) point out that the a priori segmentation method might not result in forming homogenous response groups. For example, people of the same age group or from the same geographic area might react differently to marketing efforts. At the same time, the post hoc method might lead to misconceptions and subjective conclusions as the segmentation process itself depends to a large extent on a researcher (Dolnicar \& Grün, 2008). Therefore, in each case market segmentation procedures must be preceded by a careful study of the situation and circumstances that might influence the choice of segmentation methodology.

\subsubsection{Market segmentation in the cruise industry}

As a branch of the tourism industry in general, the cruise industry benefits greatly from the application of target marketing; in the process of segmenting cruise passengers, when targeting passenger segments and adjusting products to them, general segmentation theories and techniques are widely used (Bowen, 1998). The specifics of the industry nevertheless call for changes and improved precision in target marketing practices (Bhadauria \& Sanjoy Ghose, 2014). Some of the most useful segmentation methodologies in the cruise industry include three aspects of segmentation.

a) Geographic segmentation is necessary because any single cruise trip starts at a specific port, and in most cases the passengers come from surrounding regions (at least from the same or neighbouring country), but of course in order to take a cruise passengers sometimes arrive in the port city by air or some other mode of transport. It is also 
often the case that the company's entire cruise portfolio departs from ports in one or a few countries in one region.

b) The family cycle stage is extremely relevant in the cruise industry. This variable greatly influences passengers' requirements as to a ship's facilities, activities and entertainment on-board. There are ships that cater for the needs and interests of several groups, or all, to some extent, within this classification, but there are also the ships focusing only on one or two groups (for example, adult only ships or, the opposite, family-friendly ships).

c) Income is significant because cruises still largely pertain to a luxury product category, even though recently cruise companies have paid increasing attention to the middle class and to younger, less affluent customers.

Socio-demographic segmentation is often used by organizations in the cruise industry, such as Cruise Lines International Association (CLIA), GP Wild, and the cruise companies (Gross \& Lueck, 2011; Vogel, Papathanassis, \& Wolber, 2012). DVB Bank, (2004) distinguishes between five segments according to socio-economic approach: Budget, Contemporary, Premium, Luxury, and Ultra Luxury. This classification is mainly based on the price, quality and originality of a cruise trip. The further up the scale the segment is from "budget" to "ultra luxury", the higher the price and the higher the quality of service, food, facilities and other factors of the cruise experience. Wood (2004) distinguishes between four segments according to similar criteria. First, he divides the passengers into three main groups and then describes the fourth one separately. The first segment caters for budget passengers, who intend to travel cheap and accept such trade-offs as older and less luxurious ships. The next group comprises contemporary passengers, who tend to travel with large cruise lines, and covers a rather wide range in terms of prices. The third segment is for premium passengers, who can afford and buy expensive trips; they are often older than those in the other segments. The fourth group, separated from all other cruise passengers, comprises the elite, who actually own cruise chips and sail frequently.

There are other types of segmentation according to socio-economic variables. For example, Cruise Planners divide cruise lines into four groups according to these criteria (including not only price and quality, but the lifestyle on-board and the general vacation experience as well) and then segment passengers on a product basis. The groups are: (1) first class, (2) premium, (3) luxury and (4) specialty cruise lines (Cruise Planners, 2014). 
1. The first class cruise lines are characterized by large ships but small cabins, one week and shorter trips, more family friendly and activity oriented.

2. Premium cruise lines are characterized by medium-sized ships and large cabins, one week and longer trips, often mostly for adults, relaxation-oriented.

3. Luxury cruise lines are characterized by small ships and very large cabins and suites, relaxation-oriented, long trips of 10 or more days. These are less likely to be family friendly.

4. Specialty cruise lines are characterized by very small ships, few sports and entertainment facilities, usually not family friendly, but adventure-oriented.

Apart from socio-demographic and product segmentation, many other methodologies from general marketing theory can be used, such as 'first time' versus 'repeat cruisers' segmentation, benefit segmentation and lifestyle segmentation, for example. Two of the most recent interesting works dedicated to market segmentation of cruise passengers were about passengers' motivations and the reputation of cruise lines. According to Petrick (2011) a cruise line's perceived reputation has a very strong impact on cruise passengers' perceptions of price sensitivity, quality, value, satisfaction, word of mouth and repurchase intentions. In the course of his research, passengers were divided into perception groups, then the latter were compared on the variables listed above. The difference between groups proved to be significant. The motivation subject was investigated by Jones (2011). Three motivation aspects were studied: information sources, vacation attributes, and motives derived from the Leisure Motivation Scale. The research concluded that knowledge of passengers' motivations gives cruise companies good insight into the reasons for passengers' decisions to cruise and their choice of a specific cruise trip or itinerary.

\subsection{Segmentation of cruise passengers by cruise lines}

Often cruise passengers are referred to as one particular segment of tourists coming to a destination. Indeed, they have a lot in common and differ from other tourists in some respects. For example, they do not need accommodation at destination ports and only spend limited time on shore, almost in all cases under 12 hours (Associated Icelandic Ports, 2016). At the same time, however, they are not a homogenous group and vary greatly according to different factors. One might say that segmenting cruise passengers is, in a way, easier for National Tourist Offices (NTO) and local companies serving tourists, than it is with other tourists; the reason being that a large part of the work is already done for them. The lists of cruise ships arriving in the 
country are known far in advance. The group of passengers travelling on one ship is by no means completely uniform, but they have a lot in common. Each cruise line has its target market defined by multiple criteria (e.g., nationality, social status, family cycle stage, life style, benefits sought). The target market becomes even more narrowly defined at the level of each cruise ship. Therefore, by carefully studying arriving cruise ships and their owner companies, one forms an idea of what the passengers are like (Petrick, 2011).

As a result of secondary research on the target markets of various cruise ships and their owner companies, the authors noted the distinction between larger and smaller cruise lines (Cruise-Critic, 2014). Larger cruise lines comprise all the brands included in the corporations of "The Big Four" (leading cruise line companies, including; Carnival corporation, Royal Caribbean Cruises, Norwegian Cruise Line, MSC Cruises) (Chang, Lee, \& Park, 2017), whereas cruise lines not found there are referred to as smaller cruise lines for the sake of simplicity.

\subsection{Comparison of larger and smaller cruise lines}

In general, ships belonging to large cruise companies have much in common, as do the ships of smaller cruise companies. So, in what ways are the large cruise companies similar to each other from the point of view of a cruise passenger? They usually offer a well-packaged cruise vacation with the most common duration of one week, including time spent at sea and in ports (Ward, 2014). They provide passengers with a large variety of dining options and an extended range of round-the-clock entertainment, including large-scale Broadway-style shows, casinos and art auctions. They also have large shopping malls, water parks, fitness and wellness facilities. Some of the cruise lines are more traditional and stick to the conventional types of entertainment (such as mentioned above, or music concerts, or theatre shows). Others are more innovative and adventurous offering first-time-at-sea activities such as surfing or rock climbing on-board. Most of the ships have entertainment facilities and programmes for children, as well as access to the Internet. On the downside, the ships are often large, or sometimes medium sized, and crowded. This can result in the passengers spending their time waiting in lines or being unable to relax and rest calmly. Although most of the ships belonging to the large cruise companies have much in common, they nevertheless differ in a number of aspects. They vary greatly, for example, in style and decor, dress code, availability and size of various facilities, crew-to-passenger ratio, service, food and maintenance of the ship (Ward, 2014).

Smaller cruise lines operate in a different way. Unlike the large corporations, many of smaller cruise lines are still family-owned or part of a tour op- 
erator's agenda. The owners usually operate a small fleet and ships are often chartered rather than owned by a company. Most of the companies run small or medium-sized cruise ships, but there are also those who charter large resort ships as well. Many of the smaller cruise lines serve small niche markets catering for passengers' specialist tastes and needs, some offering expedition cruises and exotic destinations (Ward, 2014). Small, boutique-sized ships have their own advantages, such as an informal, relaxing atmosphere and privacy. They can also visit smaller ports which are inaccessible to the large cruise ships.

To sum up: Firstly, large cruise lines usually have larger ships than smaller cruise lines; secondly, larger cruise lines have more variety of entertainment on board, but smaller ones often provide more privacy and a relaxing atmosphere; thirdly, smaller cruise lines often serve niche markets catering for customers' special needs while larger cruise lines target mass cruise markets. Cruise passengers choose ships according to their tastes, requirements and purchasing capabilities, which means that by studying the features of a cruise ship some conclusions can be drawn about its passengers.

\subsection{Tourism market segmentation conducted by NTOs}

In order to maximize the positive impact of tourist arrivals on a destination, a country's government must work out a sound strategy and tourism objectives. For those purposes the NTOs (National Tourist Offices) are usually founded. Some of their primary responsibilities are to investigate, identify, quantify and prioritize the most attractive tourist segments for the destination concerned (ETC, 2007).

The process of prioritizing is particularly difficult for NTOs, because they have to consider various different aspects while choosing the target segments. While for-profit organizations usually assess the segments according to current or predicted profitability, NTOs have to take into consideration other tourism objectives besides profitability (such as balancing or evening out seasonality and the geographic distribution of tourist arrivals). They may also represent the interests of stakeholders in industry, especially if the NTOs are financially dependent on them. Most importantly, however, NTOs are usually not involved in the management of actual tourism products or services (hotels, restaurants, sports facilities, etc.). Based on extensive research by The European Travel Commission (ETC), fifteen segmentation methodologies can be applied to the tourist market: socio-demographic segmentation; purpose of trip; visiting friends and relatives (VFR); trip pattern and structure; 'first time' versus 'repeat visitors'; benefit; activity; motivation; lifestyle; niche market; geo-demographic; price; media audience; Internet; Business to business (ETC, 2007). 


\subsection{Marketing approach and communication}

Service providers can choose between two main approaches for marketing; business to business (B2B), in which they sell their products through an intermediary (business partner), generally travel agencies or the cruise ship companies, or directly to the end consumer (business to consumers, B2C) (Coviello \& Brodie, 2001). The approach selected has an impact on suitable ways to provide information on the value and uniqueness of their offerings, and communicate with the customer. In the case of B2B, they generally communicate with their business partners who then include the information on the relevant service offering in their own combined package. However, consumers increasingly seek additional information on the internet, which makes the communication somewhat tricky, as the main objective of the service provider is to support their business partner and it is important to create trust and prevent potential conflict (Campbell, Papania, Parent, \& Cyr, 2010; Hadjikhani \& LaPlaca, 2013). In a B2C setting, the situation is different, as the service providers themselves take care of the communication and need to reach the end customer directly.

Marketing communication can be defined as a sales promotion that encourages the customer to take specific action. There are two main means of marketing communication, traditional offline channels and online channels. Increasingly both channels are used in an integrated approach where both methods support each other (Roberts \& Zahay, 2012). The internet is of particular importance in marketing communication in the tourism industry as well as in destination marketing, both to keep existing clients and secure new ones (Li, Robinson, \& Oriade, 2017; Mulholland \& Cachon, 2004). Word of mouth $(\mathrm{WoM})$ is of increasing importance in the tourism industry, where customers communicate their experiences in an open channel and customers' reviews, frequently posted on websites that offer information on products and services, through which customers can buy and pay for the services online. Various approaches are used to reach potential customers via online channels, such as websites, search engine optimization (SEO), permission marketing, blogging, and social media.

\section{Research method}

The main goal of this research was to gain an insight into cruise passengers coming to Iceland through segmentation and to learn more about the marketing communication practices directed towards them. To achieve this goal, the following research questions were posed: 1) How do people working with cruise passengers visiting Iceland experience differences between them? 2) In what ways is information on Icelandic tourist products and services communicated towards cruise passengers? A qualitative approach was found to be 
more suitable than the quantitative type, as it provides a deeper understanding of the behaviour of cruise passengers.

A decision was made to collect data through personal interviews with people who work in the tourist industry; that is, those serving cruise ship passengers, as opposed to the cruise passengers themselves. The reason was that cruise passengers would only have been able to reflect on their own experience, but not on differences between customers in different segments, which was one of the main objectives of this research. Furthermore, interviewing professional people in the industry was more practical, as it offered an opportunity, within a short time, to reflect on the experience of professionals working with customers in many segments and the difference between them.

\subsection{Participants}

Two main requirements were established in choice of interviewees:

$>$ They should work on a regular basis with cruise passengers coming to Iceland, and cruise passengers should constitute an important part of the company's customers.

$>$ They should occupy managerial and/or marketing posts in their companies and be able to see the big picture.

At first, the researchers intended to limit the participants only to those who work in local travel agencies or tour operator firms, but decided against it. Firstly, such a limitation would deprive the researchers of useful information from people who work in other companies which serve cruise passengers, such as harbour companies and stores that frequently sell products to cruise ship passengers. Secondly, there are not all that many travel agencies in Iceland which often work with cruise passengers. Several agencies which answered the request had such a small number of cruise passengers among their customers that they did not separate them from other travellers. Therefore, it was decided to omit such firms. Eventually, the respondents were chosen, and they agreed to arrange an interview. These included representatives from eight tour operators and travel agencies, one representative from a harbour company serving cruise ships and one from the tourist service centre and stores at the harbour. All of the interviewees were employed in managerial and/or marketing positions with their firms and had a good understanding of the customers their companies serve. It is noteworthy, as well, that some of respondents were also members of Cruise Iceland, an association of 26 ports and companies involved in serving cruise ships and passengers in Iceland. 
Table 4 presents a list of all interviewees who participated in the research, their employment area and the type of companies they work for.

Table 6: Interviewees' pseudonyms and companies

\begin{tabular}{lll}
\hline Pseudonym & Employment & Operation \\
\hline Interviewee 1 & Marketing & Harbour service \\
Interviewee 2 & Management & Tour/travel \\
Interviewee 3 & Marketing & Tour/travel \\
Interviewee 4 & Management & Store at the harbour \\
Interviewee 5 & Management & Tour/travel \\
Interviewee 6 & Management & Tour/travel \\
Interviewee 7 & Management & Tour/travel \\
Interviewee 8 & Management & Tour/travel \\
Interviewee 9 & Marketing & Tour/travel \\
Interviewee 10 & Management & Tour/travel \\
\hline
\end{tabular}

The interviews were conducted in Icelandic, then translated by a fellow student of one of the researchers into English. Then, the translated version was sent back to the respondent concerned who either verified that the translation represented the correct meaning and understanding, or provided corrections which were followed up. The revised version was sent again to the respondent for final verification.

\subsection{Data collection and analysis}

Participants in the research were reached either by email or phone. They were offered to choose a time and place for an interview which was usually conducted during office hours and at their workplace. This arrangement was for their convenience in order to increase the likelihood of being able to organize a meeting, and to make them more comfortable in a familiar environment. Each interviewee was informed about the purpose of the interviews and the subject of the research. They were all asked for permission to record the interview for the researchers' use when analysing data.

The interviews were conducted according to an interview frame with slight variations according to the flow of conversation. They usually began with a short explanation of the research and then proceeded to ask questions and encourage participants to express their point of view. At the end of the interviews the participants were thanked for their time and effort and the promise made that they could see the research paper when completed. Generally, the participants reacted positively to the interviews and showed an interest in the subject. The recording did not bother them, although a few did not want the full transcription of an interview to be published. 
The first question asked concerned the type of business the interviewee's firm had with cruise passengers. This question was a rather easy one for the participants, helped to warm them to the subject and was also highly informative to the researchers with respect to background. Next, interviewees' opinions about the difference between cruise passengers, recent changes, and marketing methods were discussed. All of the interviewees' responses were different, but there was a strong consistency in some of the major themes. The interviews were conducted during the period from February $4^{\text {th }}$ to April $29^{\text {th }}, 2015$. The length of the interviews ranged between 25 and 50 minutes.

After each interview had taken place, the researchers tried to transcribe it as soon as possible and highlight the main themes and categories. When the majority of interviews had been completed and transcribed, the researchers started scanning through them in search of similarities and differences in opinions and some commonly repeated patterns. When the last interview was finished, the overall data analysis was produced and conclusions were drawn.

\section{Results}

Four major themes were derived from the interviews: nationality; other differentiating factors; new trends; and marketing to cruise ship passengers. Among the first questions of the interviews were those focusing on differences the interviewees had noticed between cruise passengers and which factors could explain these differences, in their opinion. In the majority of the interviews participants spoke about nationality, size and type of ship, its luxury level and the time of year when passengers arrive.

\subsection{Nationality}

The theme of differences between cruise passengers of various nationalities came first in the majority of the interviews. In one interview it came up even before the question about differences was mentioned; the respondent started talking about nationalities while answering another question. This theme turned out to be much more strongly represented than the researchers had anticipated. While most of the respondents recognized that there were other factors influencing cruise passenger behaviour and characteristics, most of them continuously stressed the importance of the nationality of a passenger.

It's just a totally different way of thinking. Very different knowledge of the Internet, computers. Different what they want to see, different how much money they want to spend, different what they want to buy. You need different guides for different nationalities. (Interviewee 6) 
The interviewees divided cruise passengers into roughly three groups according to nationality. One group included Americans or cruise passengers from the USA. Another group was British cruise passengers. Although the United Kingdom is part of Europe, the interviewees felt that the British cruise passengers differed markedly from other European cruise passengers. And the third group consisted of Europeans, or mostly Germans. Speaking about European cruise passengers, interviewees often mentioned only Germans, since they were the largest segment; but also French, Italian and Spanish citizens. A few interviewees singled out a group of Asian cruise passengers as well. These mostly comprised Japanese and Chinese citizens. The researchers found a strong conformity in interviewees' descriptions of cruise passengers of different nationalities, their travel behaviour and specific features. Below are profiles of each nationality group of cruise passengers according to the interviewees' descriptions.

\subsubsection{American cruise passengers}

American cruise passengers were in most cases positively described. Most of the interviewees considered them good customers who are easy-going, "shop a lot" and do not give too much consideration to the price. The interviewees also stated from their experience that American cruise passengers were the highest percentage of those who look for excursion tours in Iceland by themselves instead of buying them on board. The respondents believed the most important reason for this was the absence of a language barrier, as the majority of excursions in Iceland were offered in English and there was a much larger variety of tours for English-speaking tourists. Two interviewees suggested an additional reason for American cruise passengers looking for excursions elsewhere. They argued that Americans prefer more variety, more interaction with local people and international tourist groups, instead of taking tours always with the same people from their ship. On the other hand, almost all the interviewees noted that American cruise passengers go the least often on excursions. They thought that only around half of the passengers arriving from the USA took an excursion. The other half either visited the port town (taking a walk, shopping maybe) or did not even leave the ship at all.

\subsubsection{British cruise passengers}

The attitude to British cruise passengers was mostly neutral, in a few cases a little positive, and in a few cases even somewhat negative. This can be explained by the respondents' assumption that the British cruise passengers spend considerably less money in Iceland than other major nationality groups. Some respondents also felt that the British cruise passengers are very price sensitive, considering their wealth and financial capability. 
The British are not spending much money, you see, and they find that things that cost 1000 ISK expensive. [...] British would say "What? 10 pounds? Are you joking?!" And then I sell some helicopter tour to an American for half a million [ISK]. Just "Here you go", you know, no problem. (Interviewee 4)

The British cruise passengers were also said to be the oldest, with the great majority of them over 60 years old, and considerably fewer families travelling compared to other European citizens.

\subsubsection{European cruise passengers}

All of the interviewees mentioned German (or sometimes they referred to them as German-speaking) cruise passengers as a significant segment. Some also spoke of French, Italian and Spanish passengers, but only briefly, referring to them as other European cruise passengers (with a native language other than English). It will be noted below in each case whether the description is related to German or other European cruise passengers.

The interviewees' general attitude to European and specifically German cruise passengers was either neutral or positive. Most respondents regarded them as good customers, although somewhat price-sensitive in the sense that they look for value for money. Here the interviewees sometimes compared German cruise passengers to American ones. The respondents unanimously agreed that the German cruise passengers are the highest percentage of those who took excursions in Iceland. The estimates ranged from $80 \%$ up to $95 \%$ of passengers. Another point is that the majority of European cruise passengers bought excursions on board a ship. The interviewees believed that mentality might be one of the reasons. In their opinion, the Europeans (especially Germans) were usually less interested in "breaking away from the crowd" than the Americans, for example. They appreciate more order and careful planning as well and prefer "to know what's going on". So even if Germans find and buy a tour by themselves, they "read the tour description well and know what they are buying". Nevertheless, respondents saw the language barrier as the main reason for this difference.

Even though the interviewees hoped to reach this segment of cruise passengers better by introducing more trips in their languages, they believed the difference still remained. There are many reasons for the English language to be used more in tourism in Iceland: maybe because it is in a way international, perhaps because most of the Icelandic people speak it fluently, or because a large number of tourists coming here are English speakers. But the result remains the same - the largest share of tourist information, tours and excursions are in English, and consequently, there is much more variety on offer. 
Passengers from those countries (Germany and France) tend to organize their travel through the travel companies onboard the ships and stick together as a group. The reason for this might be that we operate most of our tours in English, although we do offer other languages on our guided tours, German and French included. But still, we seem to attract more of the English speaking passengers. (Interviewee 3)

Even though it was brought up in one of the interviews that cruise passengers were usually well educated, the majority of the interviewees agreed that Europeans in general did not speak good English, especially the older generation.

\subsubsection{Different trips for different nationalities}

Another topic which came up during the interviews, while discussing various nationalities and languages and their impact on travel behaviour and experience, was that it is better to arrange trips differently and separately for each nationality group. Although not all of interviewees' companies did this, the majority were trying to separate passengers according to nationality. The language barrier was not the only issue as to why most of the interviewees felt it was better to step away from generic tours for everyone, mixing people of different nationalities together. They argued that there were many other issues that make a difference. For example, Interviewee 2 suggested an idea of organizing the same trips (or trips to the same places) differently for each nationality group.

There are many different tours, but we also make the same tours in various different ways. For one, the Golden Circle, which is the most common tour from Reykjavik. We would organize that tour differently for an American group than a German or English group. You still visit the same main sights, but a German guest doesn't want to spend much time at all at restrooms or shops. He would complain if there were too many technical stops like that, while an American guest would probably complain if he did not get an opportunity to do some shopping. It is just like that, people have different expectations. The Germans want to learn about our nature, while the Americans are more interested in the people living in the country. Therefore, our tour could be to the same places but organized very differently. (Interviewee 2) 
The interviewees explained that various characteristics of cruise passengers, such as mentality and cultural issues, strongly shaped their travel behaviour and their expectations from tours. For example, Interviewee 5 underlined the relevance of the time factor when organizing a tour. Everyone knows, that German people are very punctual. While this can be called a stereotype, it is in most cases very true; at least, when dealing with German customers, one must fulfil their expectations of punctuality. At the same time, Asian people frequently have a completely different understanding of time. For them, for example, a schedule merely performs a guiding function.

Asians are like, their understanding of the time factor is completely different. Europeans, and especially Germans, are quite specific about time. If we stop somewhere for $20 \mathrm{~min}-$ utes, then it should be 20 minutes. And many had an experience that Germans, or Europeans, were always waiting for Asians. And even had to send someone for them. It's probably also because of languages and misunderstanding. And we had an experience as well that people just walked out of the coach when they saw there were Asian passengers. They didn't want to bother waiting for them. It is just like that. Being aware of this we try to manage them between different coaches. (Interviewee 5)

For these reasons, several, although not all, interviewees claimed they were trying to separate passengers of different nationalities.

\subsection{Other differentiating factors}

While the nationality factor turned out to be the one most frequently highlighted by the interviewees, they mentioned three more.

\subsubsection{The size and type of a cruise ship}

The size and type of a cruise ship are interconnected. The majority of respondents singled out "small expedition ships" against the large "floating hotels". What is interesting is that many of the interviewees themselves, or their companies, more often dealt with passengers from the larger ships. Nevertheless, they tended to speak more positively about smaller exploration ships. They described the passengers from such ships as "well educat-

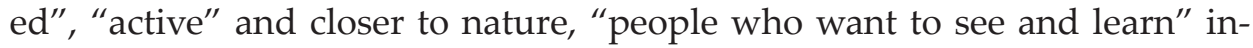
stead of "just chilling". 


\begin{abstract}
Although we get more passengers from the larger ships, we see great potential in passengers that travel on smaller expedition ships. The groups on board those ships are smaller and they go ashore on more locations across Iceland than passengers on the bigger ships. Passengers that can go ashore in rubber boats can dock at smaller harbours and explore the country in a more intimate way and get closer to nature. (Interviewee 3 )
\end{abstract}

It was also mentioned, that the small ships usually have many more trips organized in advance. Cruise ship passengers on these ships booked excursions and activities at the destination well before arrival and rarely left it until the last moment.

\title{
4.2.2 Star ratings
}

One more issue about different types of ships came up concerning the number of "stars", or star rating, a ship has, which is usually proportional to the price of the cruise trip tickets. Interviewee 2 suggested that the level of luxury on board correlated with the level of luxury (and price) of the service on shore.

The cruise passengers are quite different among themselves. Some ships have maybe 3 stars, then 4 and 5, up to 6 star ships. And the guests on board are different according to that, how the ship is. Some guests have saved for many years for their cruise, while others spend a good part of the year cruising the world on the most expensive ships. Often, in such fine ships, they have smaller groups and more individual personalized tours. Meanwhile, if the ship is of lower quality, then guests are happier with a less varied tour selection and the focus is on a few main tours. Then also groups can maybe be larger, giving the opportunity to bring the prices further down. (Interviewee 2)

A few more interviewees expressed similar opinions. Interviewee 10, for example, spoke about space on board a ship per passenger. The more the space was per person, the more the passengers were likely to order expensive private tours instead of cheap tours in large groups.

\subsubsection{The time of year}

The third differentiating factor was mentioned by roughly half of interviewees and concerned the difference between cruise passengers coming at differ- 
ent times of the year. From their point of view, there were more young people and families coming on cruise ships during the high season - from June to August. At the same time, the older cruise passengers constituted the great majority in the off season - May and September. Also, wealthier passengers came during the high season and spent more money on shore, while those who travelled off season chose more "budget" options.

There is the difference, though, between cruise passengers at different times of the year. So in late May, early June, which is kind of off season for the cruise ships, you get the budget people. You get the low income people. And by the middle of July throughout August, early September, you get the high ends. It's the high season, it's the people that have more money. People with higher incomes also tend to have better education. But that doesn't always help, depending on where they come from of course. But I do notice the big difference between early summer and late summer in type of people. (Interviewee 7)

Although interviewees considered these differentiating factors less influential than differences in nationality, they were nevertheless deemed significant. And they concerned cruise passenger segments specifically, while nationality segments were generalized for all tourists visiting Iceland.

\subsection{New trends}

Discussion of new trends and changes in cruise passengers' behaviour was initiated by the interviewees themselves in most interviews. They felt that it was a significant issue to mention and that the changes were really noticeable and fairly rapid.

\subsubsection{The Internet: independence and variety}

The interviewees spoke about the Internet and its impact on tourism and the cruise industry specifically. The Internet provides cruise passengers with a wide range of information concerning available services at destination ports, the variety of these services, and, of course, prices. Nowadays, cruise passengers are usually well aware of what is available there and can make their own decisions about what they would like to do at the destination. They do not always have to choose from a few excursion options offered on board any more.

[...] just like everywhere else in tourism service, the Internet is becoming much more important and people have also become much more independent. And there are some people 
who do not choose to go on the tours sold on-board. There is always a certain number of people who want to do their independent tours. (Interviewee 2)

Therefore, the interviewees continued, thanks to the Internet cruise passengers have become more independent. Although the majority of cruise passengers still "go the traditional way", the percentage of those who look for other options is increasing. The interviewees suggested two main reasons for that. One is a financial consideration: it is known that the cruise lines sell excursion tours at higher prices than they usually cost when bought from tour operators themselves, and the second is variety (Huijbens \& Gunnarsson, 2014; Xie, Kerstetter, \& Mattila, 2012). It is curious that the respondents seemed to be more interested in the second reason. They believed that the reason for cruise passengers looking for tours elsewhere lies in the variety itself, the variety of choice, the variety of people (opposed to the same set of fellow passengers), and more possibilities of interacting with locals and having a different experience.

In most cases, the passengers can purchase their tours at a better rate when buying straight from the local travel agency. But more than that, passengers on board the cruise ships also seem to want to travel with other people at each destination, get a taste of the local culture and then meet up with their cruise group on board the ship again. (Interviewee 3)

One of the attractive arguments in favour of separate tours is often group size. Travelling in smaller groups has multiple advantages. The service is more personal, more attention is given to each passenger and his/her special requests, and the schedule is more flexible. Some cruise passengers prefer to take it one step further and order a "private" tour for only a few people. On such tours they do not have to accept a standard itinerary within a fixed schedule or wait for someone. They are free to decide what places to visit and what they can skip and how much time they want to spend at each point of interest.

It goes two ways. On the one hand it's mostly that people are looking for smaller coaches rather than large ones. There you can have a bit more time, not having to wait in the long line to the toilet, and be in a small group. Then, it is also increasing, we now have as well, so to speak, individual tours. There are just 4, 8, 10, 12 that come together and order a car. There were many such individual tours last summer. This is also increasing. (Interviewee 5) 
Obviously, however, the flexibility is limited by the time their cruise ship is scheduled to call in at a destination port, and, needless to say, such private tours cost more per person.

\subsubsection{Younger passengers}

Another trend noted by the interviewees was that on average cruise passengers were becoming younger. Although the average age of a cruise passenger is still quite high, more and more young people and families with children are cruising each year. Interviewee 2 explained that according to the old model, only older generations went on cruises, and there was even a joke that those who go on a cruise are "the old people and their parents". Nowadays, however, this is changing.

\subsubsection{Increased popularity of smaller expedition ships}

According to the interviewees, the expedition ships described above are gaining more popularity, at least with Iceland as their destination. Until recently the tendency in the cruise industry was towards larger and more luxurious ships, but now it seems to be changing direction. The interviewees noted that the number of smaller expedition ships coming here is increasing and more passengers are interested in Icelandic nature and things to explore rather than passive entertainment.

\subsubsection{More active passengers}

An increased level of activity of cruise passengers is not only connected to the expedition ships. Interviewees believed that the behaviour of cruise passengers was changing in general towards a more activity oriented experience. This might be partially connected to cruise passengers' age, but not entirely. For example, Interviewee 2 said older passengers tend to be more active as well.

\subsubsection{Ships staying overnight}

Interviewee 1 mentioned that there was an increasing tendency for cruise ships to stop in Iceland overnight. Schedules of ships arriving in the capital area support his argument (Associated Icelandic Ports, 2016). Interviewee 1 claimed this makes a big difference for local companies catering for cruise passengers. Firstly, it gives the passengers more time to spend in Iceland. Secondly, usually on the first-day, the majority of cruise passengers visit the most popular tourist attractions, the "Golden Circle" for example. On the other hand, if they have two days, they are more likely to visit other, less popular destinations. 


\subsection{Marketing communication towards cruise ship passengers}

The question concerning marketing communication towards cruise passengers regarding products and services offered at the point of destination is more practical in nature; however, it is valuable to hear what the respondents consider the most suitable approach for marketing communication. The respondents' companies did not promote their products to cruise passengers specifically, but rather to all foreign tourists, and cruise passengers are just one segment of those. The interviewees believed the difference was not significant enough to be worth the effort. On the other hand, some of them had business connections with travel agencies, either on board ships or abroad, which promote and sell their services in Iceland. Here it is important to note that the main difference between marketing techniques chosen by companies serving cruise passengers in Iceland was whether they worked on the basis of the business to business (B2B) or the business to customer (B2C) model.

The interviews revealed that almost all marketing communication aimed directly towards end users (B2C model) took place on the Internet. In the interviewees' opinion, this was the strongest and most feasible medium for marketing communication nowadays. The interviewees also believed that the Internet almost completely sufficed for these purposes. Each of the respondents' companies had a website and, in some cases, even more than one. All the websites were fairly informative concerning the company's products and most of them had booking engines. The majority of interviewees said they were working on search engine optimization (SEO), in order for their services to be easily found. Interviewee 3 claimed they were very serious about SEO and they also used Google Ad Words. In addition, interviewee 9 mentioned "re-marketing" on the Internet (or targeted marketing).

Direct marketing (email marketing) and word-of-mouth (WOM) were also being used by the interviewees' firms. WOM in social media was specifically underlined a few times. The interviewees emphasized providing good service and building relationships with customers. Even though most passengers only come to Iceland once, some of them return. This is especially true among cruise passengers who have only one day here and come back later for a longer time.

What we have seen here also, passengers who have been here on cruise ships, we see in our customer service centre an increasing number of inquiries from people who say that they have been to Iceland on a cruise ship, stopped one day here and there. And now they want to come back with their family and do more, and visit more... That's what we've noticed. (Interviewee 9) 
And of course, most of them will share their experience with other people. Interviewee 5, for example, said that many of their customers found them because fellow passengers shared information about their tours on the cruise ships' blog. He explained that doing their job well and implementing a good pricing strategy provided them with WOM that cannot be replaced by advertising.

Another argument mentioned for direct marketing and use of the internet for marketing communication was that it offered the potential for more personal service, more personal communication and a good relationship with customers which helps service providers to build up a customer base leading to good ratings and positive word-of-mouth. One of the interviewees feels that going more into the $\mathrm{B} 2 \mathrm{~B}$ sphere implies certain sacrifices in respect of company image as well.

If we went B2B we would have to go into mass. [...] It's also a question of ethics. A question of marketing. What would we gain from going into more B2B? And sacrifice fewer than 16 [passengers on excursion tours] and go into mass. [...] All our tours are fewer than 16 people, it can't get any simpler. To sacrifice this, is huge in marketing. (Interviewee 10)

Apart from the Internet, some respondents visited trade shows and exhibitions and some advertised in the local press, such as Icelandic Times, a local magazine, aimed at tourists and the tourist industry, or published booklets. Trade shows and exhibitions were the tools almost exclusively used by companies working according to the B2B model, while the emphasis on good quality service and generation of positive WOM was valued by all of the firms. Table 4 sums up the main methods mentioned by interviewees.

Table 7: Marketing towards cruise passengers in the $\mathrm{B} 2 \mathrm{C}$ and $\mathrm{B} 2 \mathrm{~B}$ models

\begin{tabular}{ll}
\hline Business to customer (B2C) & Business to business (B2B) \\
\hline Website and Search Engine Optimization (SEO) & Building relationships with customer firms \\
Advertising on the Internet & Trade shows \\
\hline
\end{tabular}

Emphasis on good service and generating positive Word of Mouth (WOM) 


\section{Discussion}

The objective of this research was to identify differences between tourists coming to Iceland on cruise ships; what the distinguishing factors are and how products and services are marketed towards cruise passengers. A qualitative study was conducted among participants serving this specific group of customers, as this provided an understanding of the experience of marketing products towards them.

The research was guided by the following research questions:

1) How do people working with cruise passengers visiting Iceland experience differences between them?

2) In what ways is information on Icelandic tourist products and services communicated towards cruise ship passengers?

An analysis of interviews conducted revealed that cruise passengers were certainly not considered as one homogenous segment; on the contrary, the respondents felt that cruise passengers differed and could be segmented according to several factors. In general, interviewees had a fairly clear idea about cruise passengers as part of their clientele - who the passengers actually were and what they were after. Usually, however, the participants singled out cruise passengers from the others. This was mostly because they were constrained by strict time frames and of a higher age on average. Other than that, interviewees thought cruise passengers had their similarities and differences just like other tourists. As one of the first questions was about how the interviewees experienced these differences, they explained which factors they felt contributed most to the distinction and what the implications were.

The differences between passengers of various nationalities were given the most attention by interviewees. They believed that the passengers' nationality had an influence on their expectations and travel behaviour. In fact, as a result of such considerations, many interviewees, mentioned that their companies offered specially created excursion tours, tailored to the needs of passengers of different nationalities. They suggested this created higher value for customers and saved trouble for the company. This differentiation factor was completely in accordance with theoretical knowledge on segmentation in tourism. Country of origin segmentation is one of the few most used ways of segmenting incoming tourists (McCleary, Weaver, \& Hsu, 2007) and it is probably even more useful for segmenting cruise passengers, because on board a ship they usually travel in large groups of the same nationality.

However, nationality or country of origin of cruise passengers was not the only factor the interviewees found important in differentiating between them. The respondents felt that size and type of ship, its level of luxury and time of year for travelling also played important roles in differentiating one 
cruise passenger from another. Smaller ships bring more active, independent and adventurous passengers than larger ships, while more expensive ships bring more affluent, and usually more demanding, clients than the low-cost ones. The high season of mid and late summer is characterized by more families and young people cruising, as well as more high-end customers. At the same time, the low season - May, early June and late September - attracts more budget travellers and retirees. All in all, these differentiation factors can be attributed partially to a behavioural factor category which includes, for example, such variables as types of trips taken. In part, the different types of behaviour are explained by other variables such as price sensitivity, benefits sought and values. These results concur with the market segmentation proposed by both Ward (2004) and Cruise Planners (2014) who split the cruise ship market into segments based on the size of ships, offering different facilities, programmes, amenities, etc., each attracting a different type of customer.

Another important theme that interested most of the interviewees covers recent changes concerning the cruise industry and cruise passengers. The research showed noticeable changes in this sector in recent years. A couple of interviewees did not have an opinion about these changes because their companies only started serving cruise passengers a very short time ago. The remainder of the participants felt there are relevant changes going on and suggested their views on a few of them.

The prevailing trend, in the interviewees' opinion, was the independence of cruise passengers, mostly gained with the help of the Internet (Sloan, 2014). They argued that more and more passengers were aware of services available at ports of call and they wanted to be more independent from cruise lines and travel agencies on board, find trips at destinations themselves and break away from the crowd. Apart from this trend, the majority of respondents noted that cruise passengers have been becoming younger, more active and more curious with time (Elliot \& Choi, 2011; Gulliksen, 2008). The interviewees also had a feeling that recently smaller cruise ships were coming here more often. This is either because Iceland is gaining more popularity among their passengers or because large ships are slowly giving way to smaller ones. It is interesting to note that these changes the interviewees noticed among their own customers closely correspond to new trends and changes in the world-wide cruise industry as described and discussed in the relevant literature (Cruise Critic, 2014; Harpaz, 2014).

The third theme from the interviews concerned marketing communication towards cruise passengers. In general, the marketing efforts of interviewees' firms to reach cruise passengers were rather limited. The Internet was the main way of communication with clients and almost the only means for marketing activities, with a few rare exceptions such as brochures. The interviewees found the Internet highly effective, inexpensive and usually 
sufficient. Thus they did not spend much time and resources on advertising; in fact, the majority of participants even found advertising unnecessary for their companies, so it was not used there at all. On the other hand, all of the interviewees placed a strong emphasis on good service quality and a pleasant relationship with clients which results in positive word-of-mouth and a strong image.

\section{Conclusion}

All things considered, cruise passengers, both "are" and "are not" one segment of tourists coming to Iceland. On the one hand, they are, because they have important characteristics in common which differ radically from those of other tourists (length of stay and no need for accommodation, for instance). On the other hand, they do not all fall into the same category, because they are a heterogeneous group, and can be divided into segments according to several criteria. Consequently these segments can be approached from different angles, and thus value propositions and marketing activities can be designed and delivered separately to each segment. Having this information at hand, it is then up to local businesses and national travel organizations (NTOs) to decide whether to address all of the segments or only some of them, and whether to address them in different ways or in the same way.

As for marketing, its improvement does not have to be directed at increasing the number of cruise passengers at the present moment; most of the respondents claim they have enough customers for the size of their firms. The question is rather how, and whether or not, to create an opportunity for cruise passengers to spend more money per person at the destination. There is no consensus regarding whether cruise passengers should spend more money on shore or not. Some argue that passengers stay for such a short time at a destination that they simply do not have the time to spend more; others say that services provided for them are already quite expensive and the prices should not be raised - as higher prices would lead to the country losing incoming cruise passengers. These arguments make good sense, one cannot take a cruise passenger on two long excursion tours within 8 hours and one cannot raise prices beyond what the product is actually worth. But there are other ways out.

The easiest way to acquire more for selling a product/service is to enhance it to create added value. If it is an excursion for example, a seller can offer extra comfort, personalized service, complimentary gifts, food, professional photography or some activity included in the price. There are no limits as to ideas in this sphere and the product/service can be made valuable and unique with the help of imagination and careful planning. These things, of course, are already done by some travel agencies and tour operators, but are still rare compared to generic excursion products. It is certainly possible to 
argue that many tourists still go for the cheapest and simplest tours, but the researchers are convinced that there is more demand for such unique tours than it is generally realized, and that this segment is growing.

Another issue is that customers stay only for a limited time at each destination and it would be valuable to have more time to approach the customer. When cruise schedules for the next season become available, and one sees that promising ships are staying in Iceland only for 6 or 8 hours, there is nothing that can be done at that point. All efforts, therefore, should be prepared much longer in advance and be directed towards both parties; cruise lines and cruise passengers. One of the most important points to keep in mind is having a well-organized and customer friendly website which is easily spotted on the internet as this could attract customers surfing for options while on-board. In order to make cruise lines more interested in staying longer at a destination, port authorities could create an appropriate price policy (for example, the longer the stay, the less is the payment per time unit). This planning is of course not all that simple, and a lot of issues should be taken into consideration, but the point is that port authorities should take an active part in the development of sustainable inbound cruise tourism instead of competing with one another for the cruise ships.

It is, however, probably even more important to make cruise passengers themselves interested in staying longer in Iceland, because if they demand this, cruise lines will have to provide the service, a so-called "pull" approach to marketing. Most likely this will not work with all cruise passengers, as many of them cruise for the sake of cruising and do not focus on destinations. Nevertheless, as came up during the interviews, many cruise passengers "can't get enough of it" after spending a few hours in Iceland. This means that many of them would stay longer if they had the choice. So, if local tourism businesses and NTOs managed to make such cruise passengers more aware of the local attractions before they book a trip, the demand for cruises with a longer stay at a destination would increase, as would (supposedly) the supply. The final method of getting more time from cruise passengers is converting them to return tourists by motivating them to visit Iceland again, be it on another cruise or by air. Thus, persuading cruise passengers to spend more time at a destination is very important because this would contribute to the more even geographic distribution of tourism.

This research has provided valuable insight into an increasingly important part of the tourism industry, both for practitioners who can hopefully find an opportunity to direct their marketing efforts more efficiently towards this segment, and for academics who might identify areas of further research. This research is not without limitations; it provides an insight into cruise passengers from the perspective of those serving the customers, but not the cruise passengers themselves. Although valuable, the results of this research 
are therefore only a step on the way to a more in-depth study of cruise passengers and their behaviour. Further research could include studying cruise passengers, their segmentation and travel behaviour through quantitative methods. Further research could also be directed towards a more detailed study of the Internet as a means of marketing towards incoming tourists in general or cruise passengers in particular.

\section{Bibliography}

Associated-Icelandic-Ports (2016). Cruise calls to Reykjavik 2015, $2016 . \quad$ Retrieved from http://www.faxafloahafnir.is/category/is/skipafrettir/skemmtiferdaskip/

Bhadauria, A. B., \& Sanjoy Ghose, A. (2014). Demographic Segmentation of the Cruise Industry. Global Journal of Management And Business Research, 14(3).

Boston-Consulting-Group (2013). Northern Sights: The future of tourism in Iceland. Retrieved from http://www.ferdamalastofa.is/en/moya/news/northern-sights-the-future-of-tourism-in-iceland

Bowen, J. T. (1998). Market segmentation in hospitality research: no longer a sequential process. International Journal of Contemporary Hospitality Management, 10(7), 289-296.

Campbell, C., Papania, L., Parent, M., \& Cyr, D. (2010). An exploratory study into brand alignment in B2B relationships. Industrial Marketing Management, 39(5), 712-720. doi:https://doi.org/10.1016/j.indmarman.2010.02.009

Chang, Y.-T., Lee, S., \& Park, H. (2017). Efficiency analysis of major cruise lines. Tourism Management, 58, 78-88. doi:http://dx.doi.org/10.1016/j.tourman.2016.10.012

Coviello, N. E., \& Brodie, R. J. (2001). Contemporary marketing practices of consumer and business-to-business firms: how different are they? Journal of Business $\mathcal{E}$ Industrial Marketing, 16(5), 382-400.

Cruise-Critic (2014). Cruise Critic's Top 14 Cruise Trends for 2014. Retrieved from http:// www.cruisecritic.com/articles.cfm?ID=1575

Cruise-Planners (2014). Cruise Line Market Segmentation. Retrieved from http://www. marvelcruises.com/site/Market+segmentation

Dibb, S. (2001). New millennium, new segments: moving towards the segment of one? Journal of Strategic Marketing, 9(3), 193-213. doi:10.1080/096525401301420134

Dickson, P. R., \& Ginter, J. L. (1987). Market Segmentation, Product Differentiation, and Marketing Strategy. Journal of Marketing, 51(2), 1-10. doi:10.2307/1251125

Dolnicar, S. (2002). A review of data-driven market segmentation in tourism. Journal of Travel \& Tourism Marketing, 12(1), 1-22.

Elliot, S., \& Choi, H. C. (2011). Motivational considerations of the new generations of cruising. Journal of Hospitality and Tourism Management, 18(1), 41-47.

ETC, E.T.C. (2007). Handbook on tourism market segmentation: maximising marketing effectiveness: World Tourism Organization (WTO).

European-Travel-Commission (2007). Handbook on tourism market segmentation: maximising marketing effectiveness: World Tourism Organization (WTO).

Gross, S., \& Lueck, M. (2011). Cruise Line Strategies for Keeping Afloat. In M. Vogel, A. Papathanassis, \& B. Wolber (Eds.), The Business and Management of Ocean Cruises.

Gulliksen, V. (2008). The cruise industry. Society, 45(4), 342-344.

Hadjikhani, A., \& LaPlaca, P. (2013). Development of B2B marketing theory. Industrial Marketing Management, 42(3), 294-305. doi:https://doi.org/10.1016/j.indmarman.2013.03.011

Harpaz, B. J. (2014). 6 Cruise Industry Trends to Watch for in 2014. Retrieved from https:// skift.com/2014/01/25/6-cruise-industry-trends-to-watch-for-in-2014/ 
Huijbens, E. H., \& Gunnarsson, K. B. (2014). Skemmtiferðaskip við Ísland. Úttekt á áhrifum [Cruise vessels in Iceland. Report on scope and general impact]. Retrieved from http:// www.ferdamalastofa.is/is/tolur-og-utgafur/utgefid-efni/umfang-og-ahrif/skemmtiferdaskip-vid-island-uttekt-a-ahrifum

Icelandic-Tourist-Board (2016). Numbers of foreign visitors to Iceland. Research \& Statistics. Retrieved from http://www.ferdamalastofa.is/en/recearch-and-statistics/numbers-of-foreign-visitors

Jones, R. V. (2011). Motivations to cruise: An itinerary and cruise experience study. Journal of Hospitality and Tourism Management, 18(1), 30-40.

Larsen, S., Wolff, K., Marnburg, E., \& Øgaard, T. (2013). Belly full, purse closed: Cruise line passengers' expenditures. Tourism Management Perspectives, 6, 142-148.

Li, S. C. H., Robinson, P., \& Oriade, A. (2017). Destination marketing: The use of technology since the millennium. Journal of Destination Marketing $\mathcal{E}$ Management, Article in Press. doi:https://doi.org/10.1016/j.jdmm.2017.04.008

Lilien, G. L., \& Rangaswamy, A. (2004). Marketing Engineering, Revised Second Edition: CreateSpace Independent Publishing Platform.

McCleary, K. W., Weaver, P. A., \& Hsu, C. H. (2007). The relationship between international leisure travelers' origin country and product satisfaction, value, service quality, and intent to return. Journal of Travel \& Tourism Marketing, 21(2-3), 117-130.

Moscardo, G., Pearce, P., Morrison, A., Green, D., \& O’Leary, J. T. (2000). Developing a Typology for Understanding Visiting Friends and Relatives Markets. Journal of Travel research, 38(3), 251-259. doi:doi:10.1177/004728750003800307

Mulholland, R., \& Cachon, J. C. (2004). Online Marketing Communication in the Tourism Industry: An Exploratory Study of Website Effectiveness Among Tourist Lodge Operators in Northern Ontario. Journal of Small Business \& Entrepreneurship, 17(3), 175-186. do i:10.1080/08276331.2004.10593318

Óladóttir, O. Р. (2015a). Tourism in Iceland in Figures: - April 2015. Retrieved from Reykjavik, Iceland: http://www.ferdamalastofa.is/static/files/ferdamalastofa/Frettamyndir/2015/ mai/tourism-in-iceland-in-figures_15.pdf

Óladóttir, O. P. (2015b). Tourism in Iceland in figures: april 2015. Retrieved from Reykjavik, Iceland: http://www.ferdamalastofa.is/static/files/ferdamalastofa/Frettamyndir/2015/ mai/tourism-in-iceland-in-figures_15.pdf

Peppers, D., \& Martha, R. (1994). One to One B2B : Customer Development Strategies for the Business-to-Business World (1st. edition.): Piatkus Books.

Peppers, D., \& Martha, R. (2001). One to One B2B : Customer Development Strategies for the Business-to-Business World (1st. edition): Doubleday.

Petrick, J. F. (2011). Segmenting cruise passengers with perceived reputation. Journal of Hospitality and Tourism Management, 18(1), 48-53.

PKF (2013). Long-term strategy for the Icelandic tourism industry. Retrieved from Reykjavik, Iceland: http://www.islandsstofa.is/files/final-long-term-strategy-for-icelandic-tourism-industry-270213kh.pdf

Planners, C. (2014). Cruise line market segmentation. Retrieved from http://www.marvelcruises.com/site/Market+segmentation

Roberts, M. L., \& Zahay, D. (2012). Internet Marketing: Integrating Online and Offline Strategies (3rd. edition): Cengage Learning.

Rossi, P. E., McCulloch, R. E., \& Allenby, G. M. (1996). The Value of Purchase History Data in Target Marketing. Marketing Science, 15(4), 321-340.

Seaton, A. V., \& Bennett, M. M. (1996). Marketing Tourism Products: Concepts, issues, cases: Cengage Learning.

Sloan, G. (2014, Sept. 9, 2014). Another major cruise line to offer free Internet. USA Today. 
Retrieved from http://www.usatoday.com/story/cruiselog/2014/09/09/oceania-cruises-free-internet/15324875/

Smith, N. C., \& Cooper-Martin, E. (1997). Ethics and target marketing: The role of product harm and consumer vulnerability. The Journal of Marketing, 1(20).

The-Boston-Consulting-Group (2013). Northern Sights: The future of tourism in Iceland - A perspective from The Boston Consulting Group. Retrieved from http://www.icelandictourism.is/servlet/file/store36/item699669/version1/report $\% 20$ from $\% 20$ bcg $\% 20$ on $\% 20$ the $\% 20$ future $\% 20$ of $\% 20$ tourism\%20in\%20iceland.pdf

Vogel, M., Papathanassis, A., \& Wolber, B. (2012). The business and management of ocean cruises: CABI.

Ward, D. (2014). Berlitz Cruising E Cruise Ships 2015: Berlitz Travel.

Wood, R. (2004). Cruise ships: deterritorialized destinations. Tourism and transport: Issues and agenda for the new millenium, 133-145.

Xie, H., Kerstetter, D. L., \& Mattila, A. S. (2012). The attributes of a cruise ship that influence the decision making of cruisers and potential cruisers. International Journal of Hospitality Management, 31(1), 152-159. doi:https://doi.org/10.1016/j.ijhm.2011.03.007 


\section{Appendix}

\section{The Interview frame}

1. Working at your company, how often do you have to deal with cruise passengers?

2. How much would you say cruise passengers differ from each other?

a. In what ways?

3. What is your opinion about different groups of cruise passengers?

4. Do you prefer a particular group of cruise passengers over others?

a. Why?

5. Can you describe these passengers?

6. Why do you give your preference to them?

7. How much in your opinion has the cruise industry in Iceland changed recently?

8. In what ways has it changed, do you feel?

9. What is your attitude towards the changes?

10. How do you usually reach cruise passengers/ or they reach you?

11. How do you market your products to cruise passengers?

12. Which methods do you find most useful?
a. Why?

13. Do you use different methods in marketing to Business-to-Business (B2B) or Business to Consumers (B2C) customers?

14. Why did you choose to emphasize the B2B / B2C model?

15. What are the benefits of using that model in your view?

The article is based on Irena's Master's dissertation at the University of Iceland, School of Business, under the supervision of Dr. Gunnar Óskarsson. We should like to express our gratitude to the large number of parties involved in tourism who participated in the research. We should also like to thank Edward Huijbens at the Icelandic Tourism Research Centre for his helpful advice and suggestions. 
